\title{
Organized Futures. On the Ambiguity of the Digital Absorption of Uncertainty
}

\author{
Thomas Wendt * \\ University of Trier, Trier, Germany
}

Digitalization primarily takes place in and through organizations. Despite this prominent role, however, the importance of organizational structure-building processes in the digital transformation is still underexposed in discourse. The fact that ongoing digitalization is linked to an established phenomenon and its own logic, is regularly not addressed due to the attraction potential of the semantics of the digital revolution. Digital revolution and the reordering of societal relationships, though, manifest themselves primarily in processes of reorganization. Structural automation processes in the ongoing digital transformation are limiting the scope for action, necessitating forms of structural structurelessness in organizations that cultivate opportunities for chance. Since organizations realize their operations as a dual of structure and individual, and the principle of organization is therefore based on the complementarity of structural formality and unpredictable informality. The paper discusses the topicality of the classical form of modern organization in the digital age and reflects on approaches to a contemporary design of spaces of opportunity. The reflexive handling of future openness is the central task of

OPEN ACCESS

Edited by: Claudia Fahrenwald, Pädagogische Hochschule Oberösterreich, Austria

Reviewed by:

Francis Thaise A. Cimene, University of Science and Technology of Southern Philippines, Philippines Shahla Ghobadi, University of Leeds, United Kingdom

${ }^{*}$ Correspondence:

Thomas Wendt wendtth@uni-trier.de

Received: 21 April 2020 Accepted: 08 January 2021 Published: 19 February 2021

Citation: Wendt T (2021) Organized Futures. On the Ambiguity of the Digital Absorption of Uncertainty.

Front. Educ. 6:554336. doi: 10.3389/feduc.2021.554336 management and leadership in order to enable variation and innovation in organizations.

Keywords: organization theory, management, digitalization, innovation, spaces of opportunity

\section{INTRODUCTION}

Digitalization primarily takes place in and through organizations. Despite this prominent role, however, the importance of organizational structure-building processes in the digital transformation is still discursively underexposed. Digitalization narratives regularly highlight a serious upheaval that affects or will affect all spheres of social life. As a specific form of societal crisis communication, narratives of disruption in particular are part of the semantics of the digital revolution. But unprecedented challenges also require unprecedented solutions. With regard to the digital transformation, hope and alarmism therefore regularly go hand in hand. Because of the attraction potential of the semantics of revolution, however, the fact that ongoing digitalization also has something to do with an established phenomenon and its own logic is regularly not addressed. However, digitalization primarily refers to the form of modern organization and its fundamental affinity for data. Narratives of disruption, though, overshadow the importance of organizational structure-building processes in the digital transformation. Organizational structures generate and constrain organizational opportunities. The associated historically grown continuity of data-driven control affinity suggests the use of software solutions. The structure-effective use of software solutions is along a continuity line of the design of modern organizations. Digital revolution and the reordering of societal relations therefore manifest primarily in processes of reorganization. However, this line of continuity in the formation of organizational structures is not identical with the 
fact that societal relations remain the same. Rather, the scope for action and decision-making in organizations is reconfigured through the use of software solutions. The fact that the ongoing digital transformation limits organizational scope for action through processes of structural automation necessitates forms of structural structurelessness as educational arrangements that cultivate opportunities for chance. For organizations realize their operations as a dual of structure and individual. The principle of organization is therefore based on the complementarity of structural formality and incalculable informality. Especially an educational perspective traditionally understands how to deal with uncertainty and the opacity of social processes based on the unpredictability of the individuals involved. To continue their operations and foster innovation, therefore, organizations rely on educational practices of context management that productively turn the unpredictability of socialdynamic interaction through the use of methods. This is particularly the case when innovation addresses structural changes and is not limited to the level of semantics. For this reason, innovative solutions in the digitized era should not be understood as exclusively technical or computational, but are also, above all, social solutions. Variation and innovation emerge on the basis of social processes. The paper discusses the topicality of the classical form of modern organization and reflects on the potential of a contemporary arrangement of spaces of opportunity in the digital age. Reflective handling of future openness is the central task of management and leadership in the digitized era of modernity in order to enable variation and innovation in organizations.

\section{THE DIGITAL TRANSFORMATION OF SOCIETY}

The terms work 4.0 and industry 4.0 refer to a connection between digitalization and the previous waves of industrialization. After mechanization, electrification and automation, the algorithm-based interlinking of control units and the internet of things are also claiming their own index number. As the latest variant of industrial upheaval, the digital revolution is seen as fundamentally reordering societal relationships, value creation processes and the character of workplaces (Tapscott 1996). A steadily increasing data throughput shortens innovation cycles, while at the same time accelerating the speed at which ideas, products and services are disseminated (Lupton 2015). The transformation of modern conditions is accelerated in a computational way and the more and more digitized modernity reveals features of the next society (Baecker 2007). This is also represented by the acronym VUCA, which corresponds to the common scheme of modernization theories (Reckwitz 2016) in that it serves the idea of a function of increase.

In contrast to previous technology-driven industrial revolutionary upheavals, however, the digital transformation is not only fostering the emergence of new markets. Classically location-based organizations are being pressured into action. Digitalization relativizes the principle of being bound to one location (Manhart and Wendt 2019). Data streams that do not stop at territorial borders or the boundaries of organizations are increasingly relevant to growth and existence (Turco 2016). This also means, however, that questions of social and economic development increasingly come into view organizationally via processes of technical information processing (Zuboff 2018). For this reason, organizations are making increasing use of software solutions as part of their structure-building processes. As a result of increased environmental dynamics, digital-based applications should enable monitoring, control and thus also planning reliability. Digitalization in organizations follows the aspiration to avoid the well-known rationality pathologies of the organization (Brunsson 2006) - the idling of planning and its unintended effects. Digital transformation regularly means reorganization. Accordingly, the organizational worlds are changing in shape and, as a result, the relationship between organizational structures and the individuals involved is changing as well. It is remarkable, however, that the digital project is part of a long-term process in terms of how organizations deal with external and internal intransparency and the associated uncertainty. Societal complexity is inextricably linked to the principle of organization (Manhart and Wendt 2020), although organizations are internally based on the principles of regularity and procedurality (Luhmann 1976). However, the regularity and the organizational affinity for order are rarely addressed in view of the progressing digitalization. This is because supposedly more significant issues are regularly in the spotlight. The Future of Work (Herzog 2019), issues in the context of Big Data (Mayer-Schönberger and Cukier 2013), and thus also the question of what constitutes sociality in the digital age (Muhle 2018). But the principle of organization actually relates more to the present and future of societal conditions than supposedly overshadowed routines and processes would suggest (Wendt 2020a). The digital project is closely linked to the functional logic of organizations.

\section{ORGANIZATION AND THE FORGETFULNESS OF THE FUTURE}

The principle of organization serves to ensure orderly processes and regulated procedures. For this reason, organizations rely on the mechanism of structure formation (Luhmann 2006). Chaos, irregularity and randomness are not structural principles of organizations. Workplace descriptions, responsibilities and hierarchical constellations function as order-giving factors by systematically limiting the possibilities of action of the individuals involved (Whyte 1956). In organizations, only certain things are possible. Securing organizational expectations and guidelines for action therefore takes on a central role. Organizations, after all, realize their operations as a dual of structure and individual (Wendt 2019; Wendt 2020b; Wendt 2021). Organizational expectations and associated behavioral requirements meet individual demands, interests and abilities. However, the idiosyncrasies and opaqueness of the individuals involved mean that organizations always face uncertainty, which must be contained. The opacity of organizational members, the fact 
that their inner lives remain unpredictable, is precisely the problem that forces the differentiation of structures in order to create predictability.

The decision-making processes of organizations are always limited by structure-building processes. But that also means that organizations often focus more on the past than the future. In fact, the principle of organization stands for a specific form of time binding. Organizations aim to anticipate their own future through processes of structure formation, because structural specifications are simultaneously a prediction of needed behavior (March and Simon, 1958). Who has which task? When, where and how is it processed? The principle of organized division of labor is based on a planned anticipation of the future (Wendt 2019). Organizational structures are mechanisms of limiting contingency, and the answer to understanding the future is found in the structure-building processes of the past. Organizational routine, which is procedural and regulated, has the function of avoiding randomness and of making the organization not dependent on the individuals involved, in order to avoid putting its own time stability at risk (Coleman 1979). Organization means anticipating through structure formation what will happen and in this respect is a special mode of preoccupation of the future (Wendt 2019, Wendt 2020b). Structures determine options for action and, by structurally shaping them, determine the future of the organization (Chandler 1962). The order of the organization is therefore also the price for opportunities remaining unused. Determining options for action has a negative impact on the potential for flexibility. Routine and change are conflicting. Routine generates the need for change, while change depends on certain procedures, which in turn leads to the routinization of action executions (Brunsson and Olsen 1993). As a result, the challenges of the future are regularly pushed aside in the organizations' day-to-day routines.

Organizations fundamentally depend on the reciprocity of structure and individual (Barnard 1970). Reflecting on organization requires the assumption that individuals act in a structurally preformed setting and thus in a self-determined manner in externally determined contexts. Structural guidelines and organizational expectations are general guidelines that need to be respecified in the organizational day-to-day operations. Unless one assumes a technical relation, there is a moment of uncertainty in the difference between specification and respecification (Wendt and Manhart 2020). The practice of the organization is constituted in the field of tension between person-independent processes of structure formation and person-bound characteristics and competencies that are inseparably linked to the individuals involved. Individuals have abilities, skills, and knowledge that are performatively proven; this does not apply to structural specifications. The fact that the mechanism of organization integrates motive generalization in addition to behavioral specification (Luhmann 1975, p. 13) implies that assumed individuality must be shaped in the process of planning (Lehmann 2011). This construction in particular shows the educational demand level of organizations, since the willingness to acknowledge artificial measures is based on reflexive distancing.

Working on the structure of the organization classically corresponds to the task of management (Wendt 2020a). Since the beginning of modern management theory, the goal of successful organization has been attempted to be realized through various forms of structure formation. These include, for example, methods of measuring work processes (Taylor 1919), the calculation of the organization (Gutenberg 1929) or the visualization of organizational action (Gilbreth 1921). The classic management aspiration is to contain the uncertainty of the moment with the help of structure-forming processes and thus to guide behavior in a goal-oriented manner in order to ensure that organizational processes are free of disruptions. Opening and closing organizational spaces of opportunity occurs through work on the structure of the organization. In constraining and generating opportunities at the same time, the management of organizations therefore realizes itself as a genuinely educational practice (Wendt 2020a; Manhart and Wendt 2020). The actionguiding efficacy of organizational structures disposes over opportunities and the extent to which person-bound potentials can be expressed.

In order to ensure its routine functioning and to establish reliable procedures, the organization uses a series of practices of blocking spontaneous and arbitrary actions. Forms, files and lists define what is possible within the organization. As a result, the use of regulatory notation systems leads to a data affinity of the organization. An available data base relativizes the fluidity of the moment and enables case-based processing across different responsibilities, departments and hierarchical levels, which is not dependent on single individuals. The logic of the organization suggests the use of digital structure-building tools and thus forms of data-based contingency management. The organization's affinity for data and the increasing effectiveness of algorithm-based structure formation mean that reorganization and digitalization are increasingly becoming synonymous. Progressive digitalization in particular can work into the hands of the organizational forgetfulness of the future.

\section{DIGITALIZATION AS REORGANIZATION}

Understanding the form of modern organization as a dual of structure and individual makes it possible to focus on the path of organizational theory and management theory into the digital age along a predefined line of continuity (Wendt 2020a). From this perspective, digital transformation is less a revolutionary event than a continuation of existing organizational options. With this in mind, the fact that software solutions are becoming increasingly influential in organizational structuring (Aneesh 2009) is not exclusively new and digitalization-related, but should also be understood as a further chapter in the history of how modern organizations are structured. Software solutions also determine what is possible within the organization. Novelty is a matter of perspective. The new is already contained in the old, just as the old can still be found in the new (Manhart 2014). This also applies to organizational structure formation. In the history 
of organization and management, new chapters stand not only for the continuation of established conditions, but also for updating them.

The ongoing digitalization implies that the part of algorithmbased computing processes is increasing in organizations. Algorithm-based software solutions such as digital documentation applications, standard business software, or digital case management systems extend the course of form use, file regularity, and list formality, which have always been applied as forms of data-based control in organizations on the planning side (Wendt and Manhart 2020). While the use of files, lists and forms already preforms the available options for action, this also applies to software solutions that represent a new i.e., digital, form of structuring processes (Kelkar 2018). Organizational options, however, are now increasingly found visualized on screens in the form of tabs and buttons, or are depicted on displays as in app-based platform solutions. What is possible in organizations now results from input possibilities and is shifted towards dynamic interfaces. Thus, shaping organizational opportunities shifts toward the side of organizational structure formation.

In the course of digitalization-induced reorganization, the relationship between structure and the individual is changing in that individual scope for action is being rearranged (Pors 2015). Human consciousnesses cannot be involved in the computational operations because of their speed. During application, the mathematical routine behind it remains hidden (Pasquale 2015). Due to the fact that the participation of individuals remains limited to the observation of structural specifications mapped onto displays (Pariser 2011), individual scope for action dwindles in organizations. Despite the supposed analogy of "analog" and "digital" structure formation (Büchner 2018), a readjustment of the initial constellation is the consequence. The computational routine of the software creates a substitutability of the user (Acemoglu and Restrepo 2019). Based on computation, the principle of independence of persons reaches a new high (Reichmann 2019). On the operational level, calculation-based connectivity makes personbound potentials such as experience-based intuition, momentdependent perceptual ability, or case-based application knowledge superfluous (Beer 2017). Processing algorithms are not contingent, so alternatives are computationally excluded (Bartlett 2018). Structural elements of organizations become fixed coupled (Heiland 2018). The linkages of numbers are mathematically regulated and so the claim to conceptualize the organization as an interconnection of technical relations (Ezzamel et al., 1990) in planning terms can be realized in the form of a calculating machine. The classic data affinity of the organization is thus supported by new tools (Wendt and Manhart 2020). This is extremely functional for ensuring organizational processes.

Software solutions shift the organizational dual of structure and individual toward the side of structure. From this perspective, digitalization is a mode of dealing with uncertainty resulting from the participation of individuals. The undermining of organizational expectations in organizations is always a consequence of the peculiarity of the individuals involved and, at the same time, of practices that are not calculable. Classically, this is illustrated by the distinction between formality and informality (Tacke et al., 2015). For forms of oral tradition and related forms of collegiality it must be assumed that, first, they depend on the individuals involved and, second, as languagebased communication, they always provide opportunities for misunderstanding. Because empirically, consensus is pure chance. This uncertainty, typical of communication, is erased by computational connectivity (Manhart 2018). Thus, the relevance of communicative practices (Fahrenwald 2011) is coming under pressure, because the outsourcing of structureguided work processes into datafied orders (Duttweiler 2018) reduces individual scope for influence and possibilities for communicative negotiation. There is no need to think about how something is possibly meant. No content is to be deciphered and thus the necessity of negotiation, of person-dependent interpretation and therefore also the meaning of individuality recedes to the background. Number links and arithmetic operations are not contingent, so that the yes-no form (Luhmann 2005), which constitutes language use, does not apply.

Understanding digitalization as reorganization implies understanding the work on the organizational structure as the increasing establishment of a computation-based autologic. Progressive digitalization therefore points to the basic problem of every organization and refers to the question of the topicality of the organizational structure-individual duality. The classical principle of organization, after all, is based on the complementarity of structural formality and unpredictable informality (Roethlisberger and Dickson 2017). Predictability and unpredictability mutually increase each other.

\section{ORGANIZATIONAL SPACES OF OPPORTUNITY AS A COUNTERBALANCE TO ADVANCING DIGITALIZATION}

At first glance, when structural performance increases, the organizational relevance of the individuals involved decreases through forms of digital structuring (Danaher 2016). However, if the scope for action is reconfigured in this way, in a contrary momentum, increasing relevance is attributed to spaces of opportunity in organizations, in order to maintain the complementarity of structure and individual (Wendt 2020a). Understanding digitalization only as a decline in the relevance of individuals therefore falls short. Organizations need alternatives for decision-making in daily business (March and Simon 1958). Organizations need uncertainty, which is not absorbed computationally and thereby inhibited. This also applies to innovation that does not result from the logic of computational routine, but rather stands for leaving the path of routine (Besio 2018). This cannot be achieved by a computational continuation of the past.

The recalibration of the structure-individual duality of the organization is a central challenge of management and leadership in the digital age (Wendt 2020b). Instead of the structure-guided excommunication of chance, it is about the reintegration of the unpredictable. Organizations therefore 
face the task of structurally enabling opportunities for forms of reciprocal attention and reference. Spaces of opportunity in organizations must therefore be conceptually thought out to get members out of their offices, dissolve the anonymity of the cubicle, and productively turn the structure-led juxtaposition around (Chesbrough and Bogers 2014). Encounter, conversation, and thus controversy become organizational resources (Page 2007). Being communicative practices, they are an attempt to conceptualize the openness and contingency of the future not as an unpredictable risk, but as a reservoir of organizational opportunities. The starting point of management theory as a practice of arranging behavioral specifications with an affinity for order is therefore transformed in current concepts into the antidote of contingency-free computational operations (Wendt 2020a). Systematically excluding future openness through the mechanism of structure formation is recognized as a problem that leads to path dependencies, inflexibility, and the risk of lack of alternatives. Future openness and associated hopes take the place of future forgetfulness in contemporary management. Variation and innovation are the result of a practice that understands contingency as a productive force.

In order to sufficiently irritate themselves and not close the sources of unpredictability, organizations therefore resort to certain participatory methods and practices of fostering innovation (Schröer and Wendt 2018). Interaction-based and methodologically structured processes (Brown 2009) thus become the complement of increasingly efficient forms of computational structure formation. At the level of connectivity, the organizational complementarity of structure and individual, or calculable formality and incalculable informality, is equivalent to the difference between computation and communication. Methodological approaches and participatory methods such as simulations, gamification or scenario development, large group methods or innovation labs are examples of this. They aim to productively turn the disordered and controllably unavailable dynamics of social interaction within the organization's orderly context (Manhart et al., 2020). Instead of relying on organized computing and interference-free processes of digitalization, the focus is on communication and the uncertainty that is always associated with it as a consequence of the mutual lack of transparency of the individuals involved (Manhart and Wendt 2019). This means that the unpredictability of social interaction is systematically exploited. The organizational tension between closedness and openness is thus intended to be effective less as a restriction of opportunities and more as a catalyst for alternatives. However, the openness resulting from the intransparent and unavailable mutual references in social interaction is always unpredictable (Wendt 2019). Communication logic, after all, does not follow the logic of regulated and orderly procedures. The potential of communication is based significantly on productive coincidences, which are enabled by the simultaneous presence of the individuals involved. Methodically, the focus is primarily on the potential of the individual and the communicative generation of contingency, not on a computational negation of contingency. Computational processes recombine and analyze what is already available and are thus always oriented to the past. The future, however, requires alternatives, and that means unused opportunities.

Dealing methodically and productively with future openness is a traditional educational challenge. The paradox of structural structurelessness that marks the organization's production of contingency in order to provide the necessary openness for participation opportunities therefore follows a corresponding line of discourse. Since the question of how freedom can be cultivated through coercion (Kant 1964, p. 711) at the latest, organized education has been familiar with its role as paradox management (Handy 1994). The reciprocal limitation and production of opportunities is constitutive for the principle of organization. Organizational opportunities are always a consequence of structure-guided constraints. In organizations, negation and production of contingency relate to each other in a reciprocal way. Conceptualizing organizational spaces of opportunity therefore presupposes the reflexive handling of contingency.

Participatory methods and approaches to fostering innovation represent the renaissance of chance in the digital age. As a result, ironically, the hope of the organization becomes what was identified in the rise of management theory as the cause of the organization's failure to achieve its targeted daily routine of frictionless operation: the intransparency of the individual. Now, however, the singularity of the individual becomes relevant in the context of social dynamics, as is also practiced in the context of non-directive approaches to counseling (Wendt 2016; Wendt 2019). Variation and innovation are always results of social processes. Organizational educational interventions cultivate chance and with it the hope for irritation and variation, for novelty and innovation (Wendt 2021). They exploit the nonlinear dynamics of interactionist immediacy through a methodical support. Only the potential of chance offers the opportunity to leave the well-trodden path of routine. But in doing so, they also cultivate opportunities for individual participation. Simulations, gamifications or scenario development, the use of large group methods or innovation labs are therefore also about the democratization of the production of chance.

Relying on the systematic production of contingency and thus on the methodsupported production of alternatives in organizations is an approach that can be justified from three different perspectives. A normative perspective of claiming participation and spaces of opportunity for their own sake is only one possibility. But a normative critique, like a critique of the instrumentalization of the individuals involved, sometimes falls a bit short. The ability to develop ideas, to judge in a balanced way, the courage to make decisions and to take responsibility for them are not limited in their relevance to organizations. Despite all the justified criticism of the increasing responsibility of organizational members (Hartz 2011) due to participatory practices, the skills and abilities required to deal with contingency and complexity do point beyond the boundaries of the organization. Especially in light of the current conjuncture of complexity-reducing descriptions (Nassehi 2017), the required 
practice in dealing with uncertainty marks a central relevance for modern democracies (Manhart and Wendt 2020). Societal participation always means participation in organizations.

But for the organization, two other distinct reasons are equally important. The different modes of numerical and communicative connectivity, first, offer an approach for a semiotic argument. The mutual stabilization and enhancement of both modes on each other is constitutive for the principle of organization. Organizations cannot be reduced to an exclusive form of connectivity. This is because while linkages of numbers are not contingent, this is precisely not the case for communication and decision making (Wendt and Manhart 2020). When computing is done, no decision is made (Provost and Fawcett 2013). This leads to the third, an organizational or decision-theoretical argument. The fundamental necessity of alternatives for organizational decision-making processes and the associated contingency are at stake here. Without alternatives, there is nothing to decide. Niklas Luhmann made the corresponding statement that the organization would cease to exist in a state of complete self-determination (Luhmann 2006, p. 186). The organizational structure has the function of making decisions superfluous through the ordering of processes, whereas variation and innovation presuppose the social production of alternatives. Understanding organizational spaces of opportunity as forms of methodically generated complexity therefore also implies that variation and innovation in organizations is the result of a social process. Innovation is always social.

Contingency, complexity and future openness appear less as a risk for organizations in this context, and more as a potential to be exploited. Using and productively turning the complexity of social-dynamic interaction, as context management, however, comes down to paradoxical models of intervention. In this way, not only has the path to the age of digital organization already begun in the past. There is also a corresponding course line for the productive handling of contingency. The proximity to classical figures of educational reflection is evident, because already theories such as von Humboldt, 1960, Schleiermacher (2000) or Rousseau (1971) focus on contingencies that the world as a space of experience holds in store. Complexity generated by educational practices of context management therefore points to the topicality of classical educational theory, which early on addressed the issue of dealing with unpredictability. Not acknowledging the unpredictability of individuals and the dynamics of social interaction, educational problems would be part of machine theory, which addresses the frictionless and person-independent processing of information (Wendt and Manhart 2020). The classical concept of Bildung in particular is based on productive confrontation with the unintentional contingencies of the environment and addresses a reflexive form of self-organization (Manhart 2003; Manhart 2018). Contemporary approaches and methods are therefore not without presuppositions, but stand in a direct line of educational reflection.

\section{UNPREDICTABILITY AS THE KEY TO THE FUTURE OF THE ORGANIZATION}

The assumption that time will not forgive those who try to resist change in circumstances is part of the semantics of disruption. But at the latest when narratives of disruption become routine, it is important to reflect on the complex reciprocity of old and new. At the moment, the world of digital modernity is still the world of organization, in which structure and individual meet and therefore more than can be modeled via computational calculations and structure-forming processes.

The focus on technical links is contrasted with a spectrum of genuinely educational methods that are the result of reflection on the educational technology deficit (Luhmann and Schorr 1982). The reflexive handling of contingency therefore also functions as a complement and regulator of the ongoing digitalization. Organizational structures are compatible with democratic principles, but they regularly do not coincide with them. So the decisive question of digital transformation is the question of the individuals involved and the cultivation of their scope for action. Methodologically, this requires organizational spaces of opportunity as forms of structural structurelessness (Wendt 2020a). Taking advantage of the openness of the future is not a matter of course, considering the need for structure-building processes for organizations and their affinity for data. Variation and innovation, however, require openness to results. Participatory methods and approaches of fostering innovation are realized in dealing with contingency and are based on the reflexive handling of unpredictability. In order to be able to function as a counterbalance to the increasingly computational organizational structures resulting from digitalization, the dynamics of social interaction is seen as a source of opportunities. Solution finding and decision making in organizations do not follow a computational logic (March 1988). They are and remain unpredictable and are based on a practice that cannot be controlled in a linear-causal way due to its intransparency. The logic of organizations and their structure are therefore not the only educational issues. The same applies to methodical support for variation and innovation. In organizations, they emerge on the basis of dynamic social processes.

The reciprocity of structure and individual were constitutive for organizations until the digital age. In the digital transformation, the intra-organizational distinction of the different connectivity of numerical and communicative logic is updated. Focusing on the algorithm-based recombination of existing elements and the growing efficiency of structure formation processes, the thesis of the inferiority of the individual is obvious (Grunwald 2018). This raises the (not least socio-political) question of the non-organizable remnant that cannot be systematized in terms of computation (Nassehi 2014). In contrast, focusing on the indispensability of individuality and social dynamics for the functioning of the classical form of modern organization (Burns and Stalker, 1961), it becomes clear that the reflexive handling of contingency cannot be substituted computationally. The challenge of recalibrating the duality of structure and individual therefore frames an organizational education research program. The changing relationship between formality and informality, numerical and 
communicative self-logic, and the updated decision making allow a variety of necessary empirical questions.

One question that is currently not yet answered is: What comes after digitalization? To avoid anticipating the answer in the direction of computational self-logic, an understanding is required that organizations cannot be reduced to the execution of routines. Formalization gaps (Simon et al., 2008) present opportunities that are a prerequisite for variation and innovation. To achieve this, it is necessary to reflect on the organizational tension between restriction and enabling. History of organizational theory as a history of de- and reconstruction of classical assumptions of rationality (Becker et al., 1992) illustrates that the end of former certainties and the recognition of limits of planning and control enables hope for a future that is not yet fixed. The future holds various alternatives only because of its openness. The dialectic of

\section{REFERENCES}

Acemoglu, D., and Restrepo, P. (2019). Automation and new tasks: how technology displaces and reinstates labor. J. Econ. Perspect. 33 (2), 3-30. doi:10.1257/jep.33. 2.3

Aneesh, A. (2009). Global labor: algocratic modes of organization. Socio. Theor. 27 (4), 347-370. doi:10.1111/j.1467-9558.2009.01352.x

Baecker, D. (2007). Studien zur nächsten Gesellschaft. Frankfurt am Main: Suhrkamp Verlag.

Barnard, C. I. (1970). The functions of the executive. Thirtieth anniversary edition with an introduction by Kenneth $R$. Andrews. Cambridge, Massachusetts: Harvard University Press.

Bartlett, J. (2018). The People Vs Tech. How the internet is killing democracy (and how we save it). London: Ebury Press.

Becker, A., Küpper, W., and Ortmann, G. (1992). "Revisionen der Rationalität," in Mikropolitik. Rationalität, Macht und Spiele in Organisationen. 2., durchgesehene Auflage. Editors W. Küpper and G. Ortmann. (Opladen: Westdeutscher Verlag), 89-113.

Beer, D. (2017). The social power of algorithms. Inform. Commun. Soc. 20 (1), 1-13. doi:10.1080/1369118x.2016.1216147

Besio, C. (2018). Moral und Innovation in Organisationen. Wiesbaden: Springer Fachmedien.

Brown, T. (2009). Change by design. How design thinking transforms organizations and inspires innovation. New York: HarperCollins Publishers.

Brunsson, N. (2006). Mechanisms of hope. Maintaining the dream of the rational organization. Copenhagen: Copenhagen Business School Press.

Brunsson, N., and Olsen, J. P. (1993). The reforming organization. London and New York: Routledge.

Büchner, S. (2018). Zum Verhältnis von Digitalisierung und Organisation. Z. Soziol. 47 (5), 332-348. doi:10.1515/zfsoz-2018-0121

Burns, T., and Stalker, G. M. (1961). The management of innovation. London: Tavisstock Publications.

Chandler, A. D., Jr. (1962). Strategy and structure: chapters in the history of the industrial enterprise. Cambridge, Massachusetts und London, England: MIT Press.

Chesbrough, H., and Bogers, M. (2014). "Explicating open innovation. Clarifying an emerging paradigm for understanding innovation," in New frontiers in open innovation. Editors H. Chesbrough, W. Vanhaverbeke, and J. West (Oxford: Oxford University Press), 3-28.

Coleman, J. S. (1979). Macht und Gesellschaftsstruktur. Übersetzt und mit einem Nachwort von Viktor Vanberg. Tübingen: J. C. B. Mohr (Paul Siebeck).

Danaher, J. (2016). The threat of algocracy. Reality, resistance and accommodation. Philos. Technol. 6 (29), 245-268. doi:10.1007/s13347-015-0211-1

Duttweiler, S. (2018). "Daten statt Worte!? Bedeutungsproduktion in digitalen Selbstvermessungspraktiken," in Bedeutende Daten. Modelle, Verfahren und Praxis der Verlesung und Verdatung im Netz. Editors organization runs counter to the dialectic of digital progress in this respect: Unpredictability offers the key to the future of organization.

\section{AUTHOR CONTRIBUTIONS}

The author confirms being the sole contributor of this work and has approved it for publication.

\section{FUNDING}

The publication was funded by the Open Access Fund of Universität Trier and the German Research Foundation (DFG) within the Open Access Publishing funding programme.

T. Mämecke, J.-H. Passoth, and J. Wehner (Wiesbaden: Springer Fachmedien), 251-276.

Ezzamel, M., Hoskin, K., and Macve, R. (1990). Managing it all by numbers: a review of Johnson \& Kaplan's 'Relevance Lost'. Account. Bus. Res. 20 (78), 153-166. doi:10.1080/00014788.1990.9728873

Fahrenwald, C. (2011). Erzählen im Kontext neuer Lernkulturen. Eine bildungstheoretische Analyse im Spannungsfeld von Wissen, Lernen und Subjekt. Wiesbaden: VS Verlag für Sozialwissenschaften.

Gilbreth, F. B. (1921). Bewegungsstudien. Vorschläge zur Steigerung der Leistungsfähigkeit des Arbeiters. Freie deutsche Bearbeitung von Dr. Colin Ross. Berlin: Verlag Julius von Springer.

Grunwald, A. (2018). "Abschied vom Individuum - werden wir zu Endgeräten eines globaldigitalen Netzes," in Privatheit in der digitalen Gesellschaft. Editors S. Burk, M. Hennig, B. Heurich, T. Klepikova, M. Piegsa, M. Sixt, et al. (Berlin: Duncker \& Humblot GmbH), 35-48.

Gutenberg, E. (1929). Die Unternehmung als Gegenstand betriebswirtschaftlicher theorie. Berlin und Wien: Industrieverlag Spaeth und Linde.

Handy, C. (1994). The age of paradox. Boston, Masuchusetts: Harvard Business School Press.

Hartz, R. (2011). “Die 'Critical Management Studies' - eine Zwischenbilanz in kritischer Absicht," in Organisation und Kritik. Editors M. Bruch, W. Schaffar, and P Scheiffele. (Münster: Verlag Westfälisches Dampfboot), 211-246.

Heiland, H. (2018). "Algorithmus = Logik + Kontrolle. Algorithmisches Management und die Kontrolle der einfachen Arbeit," in Datengesellschaft. Einsichten in die Datafizierung des Sozialen. Editors D. Houben and B. Prietl. (Bielefeld: Transcript Verlag), 233-252.

Herzog, L. (2019). Die Rettung der Arbeit. Ein politischer Aufruf. Berlin: Hanser.

Kant, I. (1964). “Über Pädagogik,” in Immanuel Kant - Werke in zehn Bänden. (Bd. 10). (Wiesbaden: Insel Verlag), 695-761.

Kelkar, S. (2018). Engineering a platform: the construction of interfaces, users, organizational roles, and the division of labor. New Media Soc. 20 (7), 2629-2646. doi:10.1177/1461444817728682

Lehmann, M. (2011). Mit Individualität rechnen. Karriere als Organisations problem. WeilerswistVelbrück: Wissenschaft.

Luhmann, N. (2005). Einführung in die Theorie der Gesellschaft. Herausgegeben von Dirk Baecker. Heidelberg: Carl Auer Verlag.

Luhmann, N. (1976). Funktionen und Folgen formaler Organisation. 3rd Edn. Berlin: Duncker und Humblot.

Luhmann, N. (1975). "Interaktion, Organisation, Gesellschaft," in Ders: Soziologische Aufklärung 2. Aufsätze zur Theorie der Gesellschaft (Opladen: Westdeutscher Verlag GmbH), 9-20.

Luhmann, N. (2006). Organisation und Entscheidung. 2nd Edn. Wiesbaden: VS Verlag für Sozialwissenschaften.

Luhmann, N., and Schorr, K. E. (1982). “Das Technologiedefizit der Erziehung und die Pädagogik," in Zwischen Technologie und Selbstreferenz. Fragen an die Pädagogik. Editor Dies (Frankfurt am Main: Suhrkamp Verlag), 11-40.

Lupton, D. (2015). Digital sociology. London und New York: Routledge. 
Manhart, S. (2003). "Absichtlich unabsichtlich. Zum Verhältnis von Politik, Bildung und Pädagogik um 1800," in Erziehung in der Moderne. Festschrift für Franzjörg Baumgart. Editor D. Rustemeyer (Würzburg: Königshausen \& Neumann), 95-142.

Manhart, S. (2018). "Complex Learning and the significance of measurement," in Sustainability science. Key issues. Editors A. König and J. Ravetz (London and New York: Routledge), 296-317.

Manhart, S. (2014). "Organisiertes Veralten - veraltete Organisation? Zur Stabilität der Universität in den Neuerungsdynamiken von Wissenschaft und Reformen," in Organisation und das Neue. Beiträge der Kommission Organisationspädagogik. Editors S. M. Weber, M. Göhlich, A. Schröer, and J Schwarz. (Wiesbaden: Springer Fachmedien), 259-269.

Manhart, S., and Wendt, T. (2019). Delokalisierung, Entzeitlichung und Entpersonalisierung organisierter Pädagogik. Zur digitalen Transformation organisationaler Raumzeit und ihres Subjekts. Z. Weiterbildungsforschung. 42 (2), 235-248. doi:10.1007/s40955-019-0137-9

Manhart, S., and Wendt, T. (2020). Komplexe Organisation und organisierte Komplexität. Die Pädagogik partizipativer Organisationsgestaltung im Zeitalter des Populismus. Z. Weiterbildungsforschung. 43 (3), 377-393. doi:10.1007/ s40955-020-00169-w

Manhart, S., Wendt, T., and Schröer, A. (2020). "Individuelle Kreativität und organisierte innovation. Elemente einer organisationspädagogischen Synthese," in Organisation und Verantwortung. Jahrbuch der Sektion Organisationspädagogik. Editors C. Fahrenwald, N. Engel, and A. Schröer (Wiesbaden: VS Verlag für Sozialwissenschaften), 339-353.

March, J. G. (1988). Decisions and organizations. Oxford und New York: Basil Blackwell.

March, J. G., and Simon, H. A. (1958). Organizations. New York, London und Sydney: John Wiley \& Sons.

Mayer-Schönberger, V., and Cukier, K. (2013). Big data. Die Revolution, die unser Leben verändern wird. Übersetzung aus dem Englischen von Dagmar Mallett. 2nd Edn. München: Redline Verlag.

Muhle, F. (2018). Sozialität von und mit Robotern? Drei soziologische Antworten und eine kommunikationstheoretische Alternative. Z. Soziol. 47 (3), 147-163. doi:10.1515/zfsoz-2018-1010

Nassehi, A. (2014). "Arbeit 4.0. Was tun mit dem nicht organisierbaren Rest," in Kursbuch 179: Freiheit, Gleichheit, Ausbeutung. Editors A. Nassehi and F. Peters (Hamburg: Murmann Verlag GmbH), 135-154.

Nassehi, A. (2017). Die letzte Stunde der Wahrheit. Kritik der komplexitätsvergessenen Vernunft. Hamburg: Sven Murmann Verlagsgesellschaft mbH.

Page, S. E. (2007). The difference: how the power of diversity creates better groups, firms, schools, and societies. Princeton und Oxford: Princeton University Press.

Pariser, E. (2011). The filter bubble. What the internet is hiding from You. London: Viking.

Pasquale, F. (2015). The black box society. The secret algorithms that control money and information. Cambridge, Massachusetts und London, England: Harvard University Press.

Provost, F., and Fawcett, T. (2013). Data science and its relationship to big data and data-driven decision making. Big Data. 1 (1), 51-59. doi:10.1089/big.2013.1508

Reckwitz, A. (2016). "Die Moderne jenseits der Modernisierungstheorien," in Ders: Kreativität und soziale Praxis. Studien zur Sozial- und Gesellschaftstheorie. (Bielefeld: transcript Verlag), 139-153.

Reichmann, W. (2019). "Die Banalität des Algorithmus," in Maschinenethik. Normative Grenzen autonomer Systeme. Editors M. Rath, F. Kratz, and M Karmesin (Wiesbaden: Springer Fachmedien), 135-153.

Roethlisberger, F. J., and Dickson, W. J. (2017). Management and the worker. An account of a research program conducted by the western electric Company, Hawthorne works, Chicago, with the assistance and collaboration of Harold A. Wright. Cambridge, Massachusetts: Harvard University Press.

Rousseau, J.-J. (1971). Emil oder Über die Erziehung. Vollständige Ausgabe in neuer deutscher Fassung, besorgt von Ludwig Schmidts. Paderborn: Verlag Ferdinand Schöningh.

Schleiermacher, F. (2000). "Versuch einer Theorie des geselligen Betragens," in Ders: Texte zur Pädagogik. Kommentierte Studienausgabe. Band 1.
Herausgegeben von Michael Winkler und Jens Brachmann. Frankfurt am Main: Suhrkamp Verlag, 15-35.

Schröer, A., and Wendt, T. (2018). "Partizipationsorientierung als Forschungsstrategie der Organisationspädagogik," in Handbuch Organisationspädagogik. Editor Göhlich, Michael; Schröer, Andreas; Weber S. Maria (Wiesbaden: Springer Fachmedien), 331-342.

Simon, E. J., Porto de Albuquerque, J., and Rolf, A. (2008). "Notwendige und vorläufige Formalisierungslücken in Organisationen," in (Hg.): Digitalisierung der Arbeitswelt. Zur Neuordnung formaler und informeller Prozesse in Unternehmen. Editors F. Christiane and S.-S. Ingo (Wiesbaden: VS Verlag für Sozialwissenschaften, S. 239-261.

Pors, A. S. (2015). Becoming digital - passages to service in the digitized bureaucracy. J. Organ. Ethnogr. 4 (2), 177-192. doi:10.1108/joe-08-2014-0031

Tacke, V. (2015). "Formalität und Informalität. $\mathrm{Zu}$ einer klassischen Unterscheidung der Organisationssoziologie," in Formalität und Informalität in Organisationen. (Wiesbaden: Springer VS), 37-92.

Tapscott, D. (1996). Die digitale Revolution. Verheißungen einer vernetzen Welt die Folgen für Wirtschaft, Management und Gesellschaft. Wiesbaden: Betriebswirtschaftlicher Verlag Dr. Th. Gabler GmbH.

Taylor, F. W. (1919). Die Grundsätze wissenschaftlicher Betriebsführung. München und Berlin: R. Oldenbourg.

Turco, C. J. (2016). The conversational Firm: rethinking bureaucracy in the age of social media. New York: Columbia University Press.

von Humboldt, W. (1960). “Theorie der Bildung des Menschen. Bruchstück,” in Ders: Werke in fünf Bänden. Band 1. Schriften zur Anthropologie und Geschichte. Herausgegeben von Andreas Flitner und Klaus Giel. Stuttgart: J. G. Cotta'sche Buchhandlung, 234-240.

Wendt, T. (2021). "Die Kultivierung des Zufalls. Zum Verhältnis von organisationaler Strukturautomation und Unberechenbarkeit in der digitalen Moderne," in Organisation über Grenzen. Jahrbuch der Sektion Organisationspädagogik. Editors A. Schröer, S. Köngeter, S. Manhart, C. Schröder, and T. Wendt (Wiesbaden: VS Verlag für Sozialwissenschaften (in Press).

Wendt, T. (2019). Die moderne Suche nach Gelegenheiten. Plädoyer für eine zeitgemäße Beratung. Verhaltenstherapie und psychosoziale Praxis - VPP. 51 (2), 293-301.

Wendt, T. (2020a). Die nächste Organisation. Management auf dem Weg in die digitale Moderne. Bielefeld: transcript.

Wendt, T. (2016). Diesseits von Be- und Entschleunigung. Beratung als soziale Bearbeitung zeitlicher Komplexität. Sozial. Extra 40 (4), 33-36. doi:10.1007/ s12054-016-0063-7

Wendt, T. (2020b). "Moderation des Unverfügbaren: Führung in Zeiten von Digitalisierung und Reorganisation," in Soziologie für den öffentlichen Dienst (III). Führung: Perspektiven, Trends und Herausforderungen in Theorie und Praxis. Editor J. Groß (Hamburg: Maximilian Verlag), 17-27.

Wendt, T., and Manhart, S. (2020). Digital decision making als Entscheidung, nicht zu entscheiden. Zur Zukunft des Entscheidens in der Digitalisierung. Arbeit. Zeitschrift für Arbeitsforschung, Arbeitsgestaltung und Arbeitspolitik 29 (2), 143-160. doi:10.1515/arbeit-2020-0011

Whyte, W. H., Jr. (1956). The organization man. Garden City, New York: Doubleday \& Company, Inc.

Zuboff, S. (2018). Das Zeitalter des Überwachungskapitalismus. Aus dem Englischen von Bernhard Schmid. Frankfurt und New York: Campus Verlag.

Conflict of Interest: The author declares that the research was conducted in the absence of any commercial or financial relationships that could be construed as a potential conflict of interest.

Copyright $\odot 2021$ Wendt. This is an open-access article distributed under the terms of the Creative Commons Attribution License (CC BY). The use, distribution or reproduction in other forums is permitted, provided the original author $(s)$ and the copyright owner(s) are credited and that the original publication in this journal is cited, in accordance with accepted academic practice. No use, distribution or reproduction is permitted which does not comply with these terms. 